\title{
Youth Leisure in Cultural Space of Modern City: State and Prospects of Development
}

\section{Ocio juvenil en el espacio cultural de la ciudad moderna: estado y perspectivas de desarrollo}

\author{
Vladimir V. Baranov \\ Orenburg State University, Orenburg, Russian Federation \\ ORCID: https://orcid.org/0000-0002-9614-0272 \\ Andrey M. Savinov \\ Vyatka State University, Kirov, Russian Federation \\ ORCID: https://orcid.org/0000-0001-5158-9968
}

Gulnaz Sh. Ashrafullina

Naberezhnye Chelny Institute (Branch), Kazan (Volga region) Federal University, Naberezhnye

Chelny, Russian Federation

ORCID: https://orcid.org/0000-0003-1309-3456

\begin{abstract}
Alexandr L. Makarov
Ulyanovsk State Agrarian University named after P.A. Stolypin, Ulyanovsk, Russian Federation ORCID: https://orcid.org/0000-0002-6696-7260
\end{abstract}

\section{Alla A. Korzhanova}

Gzhel State University, Ramensky District, Russian Federation

ORCID: https://orcid.org/0000-0003-1162-2035

\section{Bika B. Dzhamalova}

North Caucasian Institute (Branch), All-Russian State University of Justice (RPA of the Ministry of Justice or Russia), Makhachkala, Russian Federation

ORCID: https://orcid.org/0000-0001-5885-3274

\section{Magomedrasul N. Magomedrasulov}

North Caucasian Institute (Branch), All-Russian State University of Justice (RPA of the Ministry of Justice or Russia), Makhachkala, Russian Federation

ORCID: https://orcid.org/0000-0001-7903-6265

\section{Received 02-12-20 Revised 02-25-20 Accepted 06-13-20 On line 06-29-20}

\section{*Correspondence}

Email: gladwal@yandex.ru
Cite as:

Baranov, V.V., Savinov, A.M., Ashrafullina, G.Sh., Makarov, A.L., Korzhanova, A.A., Dzhamalova, B.B., Magomedrasulov, M.N. (2020). Youth Leisure in Cultural Space of Modern City: State and Prospects of Development. Propósitos y Representaciones, 8 (SPE2), e643. Doi: http://dx.doi.org/10.20511/pyr2020.v8nSPE2.643 


\section{Summary}

The relevance of this article is the need to study the leisure sphere of modern youth, since free time is one of the important means of forming a young person's personality. The use of free time by young people is a kind of indicator of culture, the range of spiritual needs and interests of a particular personality of a young person. The aim of the study is to analyze the strategy of youth leisure in the cultural space of the modern city. Research methods: as a research method, we used the questionnaire method, which allows us to analyze in detail the main forms and dynamics of the development of modern youth's leisure practices living in an urban environment. Results of the research: the article considers the problems and prospects of leisure strategies' development of young people living in the city. The features of organizing youth leisure in the city are described. The preferences of young people in leisure activities are revealed. The degree of satisfaction of young people with forms of leisure is analyzed. The article considers the respondents' awareness of the work of institutions of the social and cultural sphere in organizing leisure activities for young people in the city. The reasons that prevent young people from spending leisure time in accordance with their needs are identified. Alternative forms of leisure activities are considered. The novelty and originality of the study lies in the fact that for the first time the reasons why young people do not have the opportunity to build their leisure strategy in accordance with their needs are investigated: external reasons (lack of places, disinterest of organizers, certain forms of leisure are unattractive or unprofitable for entrepreneurs); internal reasons (strong employment at work, lack of energy after work, laziness). The reasons for the lack of interaction of young people with leisure and cultural organizations (lack of time; ignorance of where to address on this issue; unwillingness of the organizers to change the situation that is, ignoring the position of young people) are determined. It is revealed that young people show little interest in leisure activities organized by the authorities, since they are formal in nature and do not correspond to the leisure preferences of young people. For the first time, the main strategies for leisure activities for young people living in the city (meetings with friends, relatives, walks, computer games, viewing content, relaxing in silence, and reading) were identified. The strategies of leisure activities that are used to a lesser extent (visiting the cinema, theater; active recreation (Cycling, skating, various sports); attending concerts, exhibitions, master classes; learning foreign languages) are considered. It is revealed that young people are not satisfied with the available leisure opportunities in the city. The reasons for discontent are determined (limited material resources in the city for interesting forms of leisure; lack of cultural and leisure institutions in the city that would meet the requirements of young people; limited choice of institutions where you can spend your free time). There is a gap between the needs of young people in the field of leisure and the activities of the city's youth policy Department, which conducts events according to its own plan, without taking into account the opinion of young people. Young people's knowledge about events is examined and the problem is determined about unawareness of cultural and entertainment events that are associated with the lack of interest of young people and lack of desire of the organizers of the Department of culture to find out what interests this age group. Alternative forms of leisure that young people would like to see in the urban environment, as well as take part in them, are identified (such as cinemas, theaters, restaurants; amusement parks, attractions, water parks, bowling; master classes, courses, exhibitions; interest clubs (language, discussion, computer); Bicycle rental, roller skates, Quad bikes, go-karts; paragliding school; industrial tourism). Practical significance: the data Obtained in this work can be used in social psychology, pedagogy, age psychology, as well as for further theoretical development of this issue.

Keywords: Student Youth; Leisure Practices; Free Time.

\section{Resumen}

La relevancia de este artículo es la necesidad de estudiar la esfera del ocio de la juventud moderna, ya que el ocio es uno de los medios importantes para formar la personalidad de un joven. El uso 
del tiempo libre por parte de los jóvenes es un tipo de indicador de cultura, el rango de necesidades e intereses espirituales de una personalidad particular de una persona joven. El objetivo del estudio es analizar la estrategia del ocio juvenil en el espacio cultural de la ciudad moderna. Métodos de investigación: como método de investigación, utilizamos el método del cuestionario, que nos permite analizar en detalle las principales formas y dinámicas de las prácticas modernas de ocio juvenil en un entorno urbano. Resultados de la investigación: artículo sobre los problemas y perspectivas del desarrollo de estrategias de ocio de los jóvenes que viven en la ciudad. Se describen las características de organizar el ocio juvenil en la ciudad. Se revelan las preferencias de los jóvenes en las actividades de ocio. Se analiza el grado de satisfacción de los jóvenes con formas de ocio. El artículo aborda la conciencia de los encuestados sobre el trabajo de las instituciones sociales y culturales en la organización de actividades de ocio para los jóvenes en la ciudad. Se identifican las razones que impiden que los jóvenes pasen tiempo libre de acuerdo con sus necesidades. Se consideran formas alternativas de actividades de ocio. La novedad y originalidad del estudio radica en el hecho de que, por primera vez, se investigan las razones por las cuales los jóvenes no tienen la oportunidad de construir su estrategia de ocio de acuerdo con sus necesidades: razones externas (falta de lugares, desinterés de los organizadores, ciertas formas de ocio no son atractivas o no son rentables para los empresarios); razones internas (empleo fuerte en el trabajo, falta de energía después del trabajo, pereza). Se determinan las razones de la falta de interacción de los jóvenes con las organizaciones culturales y de ocio (falta de tiempo; ignorancia de dónde abordar este problema; falta de voluntad de los organizadores para cambiar la situación, debido a la posición de los jóvenes). Se ha revelado que los jóvenes muestran poco interés en las actividades de ocio organizadas por las autoridades, ya que son de naturaleza formal y no se corresponden con las preferencias de ocio de los jóvenes. Por primera vez, se identificaron las principales estrategias de ocio para los jóvenes que viven en la ciudad (reuniones con amigos, familiares, caminatas, juegos de computadora, visualización de contenido, relajación en silencio y lectura). Se consideran las actividades de ocio que se utilizan en menor medida (visitar el cine, el teatro; recreación activa (ciclismo, patinaje, diversos deportes); asistir a conciertos, exposiciones, clases magistrales; aprender idiomas extranjeros). Se revela que los jóvenes no están satisfechos con las oportunidades de ocio disponibles en la ciudad. Se determinan las razones del descontento (recursos materiales limitados en la ciudad para formas de ocio interesantes; falta de instituciones culturales y de ocio en la ciudad para satisfacer las necesidades de los jóvenes; opciones limitadas de instituciones donde puede pasar su tiempo libre). Existe una brecha entre las necesidades de los jóvenes en el campo del ocio y las actividades del departamento de política juvenil de la ciudad, que lleva a cabo los eventos de acuerdo con su propio plan, sin tener en cuenta la opinión de los jóvenes. Se examina el conocimiento de los jóvenes sobre los eventos y el problema está determinado por la inevitabilidad de los eventos culturales y de entretenimiento asociados con la falta de interés de los jóvenes y la falta de deseo de los organizadores del Departamento de Cultura de averiguar qué interesa a este grupo de edad. - Se identifican formas alternativas de ocio que a los jóvenes les gustaría ver en el entorno urbano además de ser parte de ellas (como cines, teatros, restaurantes, parques de atracciones, atracciones, parques acuáticos, bolos, clases magistrales, cursos, etc. exposiciones; clubes de interés (lenguaje, discusión, computadora); alquiler de bicicletas, patines, quads, go-karts; escuela de parapente; turismo industrial). Importancia práctica: los datos obtenidos en este trabajo pueden utilizarse en psicología social, pedagogía, psicología de la edad, así como para un mayor desarrollo teórico de este tema.

Palabras clave: Juventud Estudiantil; Prácticas de Ocio; Tiempo Libre.

\section{Introduction}

For a long time, both foreign and domestic scientists have closely linked free time with leisure. Until now, researchers have not developed a single construct and content-based boundaries of social and free time of society and the individual (Eroshenko, 1986; Zharkov, 2007; Streltsov, 
2003; Bestuzhev-Lada, 1984; Vishnyak \& Tarasenko, 1988). Modern science has a wide range of leisure concepts that are based on most macro-sociological theories (Surtaev, 1999; Kiseleva \& Krasilnikov, 2005; Maskevich, 1989; Akimova, 2003; Orlov, 1983; Lukov, 2002; Baranov et al., 2019).

The social model of leisure focuses on the forms of participation of various groups in leisure activities of the social plan and on the behavioral characteristics of its participants. The main feature in all concepts is freedom for interesting activities, not freedom from the rules of human interaction. Another feature is a certain set of activities designed for recreation, entertainment, physical and spiritual development of a person (Nedoseka, 2013; Ionin, 2000; Shmelev, 1998; Tsybin \& Golubev, 1988).

In recent decades, the trend of domestication of leisure and recreational activities has increased, on the other hand, the need for socio-pedagogical management of the cultural and leisure sphere by specialists is increased who must develop and meet the ever-increasing demands and needs of various socio-demographic groups, introducing a game beginning to the activity. Thanks to the development of technologies, the virtual socio-cultural space becomes accessible to a huge number of people and gives them the opportunity to unite in communities. As the changes taking place in Russian society strengthen the desire of young people for freedom, independence and the fullest realization of their abilities, new channels for all types of selfrealization of the individual begin to emerge (Denisova \& Lenkova, 2015).

The main place among them is occupied by the virtual socio-cultural space, which due to its accessibility and widespread becomes one of the most favorable areas for the emergence of new non-institutional channels of creative and communicative self-realization of the individual. The most effective communication channels for young people are television and the Internet (Bolgov, 2003; Ponukalkina, 2008; Cherdymova et al., 2018a; Cherdymova et al., 2018b; Putilina et al., 2019).

Nowadays, the needs and interests of young people are constantly changing and growing, and the structure of leisure is becoming more complex. Free time is unevenly distributed among different groups of the population. Therefore, it is necessary to develop differentiated forms of leisure activities for different groups of the population. Different categories of people differ from each other in their needs, level of cultural and professional training, budgets of free time and attitude to it. This is exactly what should be taken into account in the work of modern cultural and leisure programs, they should offer people the most effective leisure activities in each case, freedom of choice and the possibility of changing different types of activities (Aryamova \& Nedoseka, 2012; Zhurik \& Sherstyukova, 2013; Alisov et al., 2018; Drobinskaya \& Sokolov, 1983).

The choice of a particular way of spending leisure time is determined, on the one hand, by the level of cultural development of the person himself, which is manifested in the system of his requests and goals, and on the other hand, by the opportunities that society provides him for the realization of interests. Opportunities are revealed in a system of conditions, more precisely, organizational forms that ensure the implementation of different types of leisure activities (Nikolov, 1984). This topic is of particular importance and relevance for young people. Because negative manifestations in the field of leisure are largely due to its disorganization, there is a need to determine how to regulate the leisure sphere of life activity of young people (Myalkin, 1983). Thus, leisure as a socio-cultural sphere of life of modern Russian youth requires a deep scientific understanding. The purpose of this study is to be able to make it clear that recreation serves as a buffer in preventing crime; recreational sports having a special place for young people in juvenile delinuency have an important place; and recreational activities that will be practised in the regions committing intense crime reduce the rate of crimes; but most importantly, sports recreation serves as a buffer for children and young people particularly in preventing the individuals from crime even before they commit. 
While legally criminal corresponding activities and conradictions to social values are accepted as crime, research shows that criminal tendency mostly centres around youth. When young population over 26 million is regarded, the issue comes out to be such important for Turkey.

Juvenile delinquency shows an increasing tendency all over the world; however, Turkey remains at the head of the world with forty percent. Security General Directorate data shows that in 2006 there were 31.761 thinner and baly addicted young; aged 30 and below composed the fifty percent of drug addicted individuals, ranging 57 percent between 15 and 24 aged; smoking start age decreased to the age of 9-10 and alcohol drinking start age fell to the age of 12-14. According to the the report of Substance Research and Treatment Centre, volatile substance start age is $11-12$, drug start age is $16-17$ and heroin start age is $18-19$.

When the research is examined, it is admitted that many countries use recreation as a buffer to reduce the rates and also prevent juvenile delinquency in the regions experiencing intense crime and that pretty good results and recoveries ranging to 90 percent are obtained from the applications.

Recreational activity in great demand among the young is generally sports. Recreational sports is used as a means of crime prevention. Research suggests that pursuit of recreational sports tends to deter the young from participation in crime. Crime rates decrease in the regions where recreational sports is applied while these rates increase in other regions.

Consequently, recreation and particularly sports recreation for the children and youth is one of the most effective and the cheapest method. The findings of many research absolutely prove that.

In Turkey, urgent precautions need to be taken to prevent rapidly increasing juvenile delinquency and concerned organisations should collaborate with particularly universities. Pilot scheme ought to be started in the regions which experience intensive crime and the use of sports as a protective element for crime prevention should be generalized regarding the sports as the most widespread recreational activity among the youth.

Adolescence has been described as a critical period during which involvement in physical activity might contribute to a physically active lifestyle lasting into adulthood. The empirical evidence, however, is not conclusive. In their review, Trost et al. concluded that there was sufficient evidence to upgrade the classification of activity history during childhood and youth and school sports from a repeatedly documented lack of association with adult activity to one of weak or mixed evidence of no association. The aim of the present study is to examine change and stability across global and specific indicators of leisure-time physical activity over a period of 10 years from age 13 to age 23 .

Most longitudinal studies of physical activity from adolescence to adulthood have focused on tracking , usually defined as the relative maintenance of a variable's relative position in a group over time. A number of recent long-term longitudinal studies report moderate to weak tracking coefficients .In terms of describing the development of physical activity across time, a low tracking coefficient provides limited information. The low level of tracking might reflect at least two very different situations. The first situation could be labelled "temporal fluctuation". Even small fluctuations, if continued over time, would create a low level of tracking across the period, in particular when the period between measurements is long, and the reliability of indicators is imperfect.

A quite different situation which could contribute to low tracking is that of individual differences. Several studies have indicated an average decline in activity across age.A low level 
of tracking might thus indicate that young people change at different rates across time. When individuals change at different rates, the relative order of individuals changes, leading to low tracking. Information about heterogeneity in change is essential in epidemiological studies, because such heterogeneity points to the need for both selected and universal approaches to the promotion of physical activity.

It has been suggested that tracking may be due to genetic factors or stable psychological characteristics of the individual such as psychological readiness for physical activity, or to stable conditions in the environment favouring physical activity such as high SES, or a family with high support for PA, as well as the learning of skills that may be more easily picked up at a later stage in life . Involvement in youth sports usually implies engaging in frequent and repeated behaviour in a structured environmental context, offering children and adolescents experiences of repeated physical activity in stable circumstances. Thus involvement in youth sports is likely to be an important part of their life, representing a potentially strong influence on the formation of physical activity as a habit.

Sallis et al. [18] suggested that one would expect higher tracking in activities that more easily transfer into adult activities, e.g. physical activities that can be performed outside a structured context. However, the most popular activities in adolescence are team sports such as football (soccer), usually implying the presence of a social structure such as a sports club. Telama et al. [19] argue that physical activity does not continue from youth to adulthood in the form of specific sports, in the sense that the types of activities adults participate in are usually different from common youth activities. The present theoretical and empirical understanding of the influence of various types of structured and unstructured physical activity during adolescence on adult physical activity is weak.

Participation in organized youth sports has been found to be consistently associated with a higher level of adult physical activity. One of the few studies reporting the tracking of specific types of sports, and the effect of these on adult physical activity in general, is the 1966 birth cohort study from North Finland [. Adolescent participation in ball games at age 14 was associated with participation in ball games, as well as with general physical activity level, at age 31 in males. The same was the case for cross-country skiing and running. In females, adolescent participation in gymnastics and cycling was found to track into adulthood, while participation in ball games was not significantly related to later activity. The study may have several limitations, notably that it is difficult to assess whether these findings can be generalized to other populations. Types and organization of youth sports may vary between countries, and may also have changed for generations born later than 1966, suggesting a need for further studies.

With this background, the present study aims to examine change and stability in global and specific types of leisure-time physical activity during adolescence and young adulthood. More specifically, the research questions are:

- To what extent do participation in global leisure time physical activity and recreational activities change during ages 13 to 23 ?

- To what extent is changes in participation in global leisure time physical activity and recreational activity interrelated?

- To what extent does baseline level of participation in global leisure time physical activity and recreational activity predict subsequent participation during ages 14 to 23 ?

- To what extent does participation in specific types of leisure-time physical activity track from ages 15 to 23 ?

- To what extent does participation in several specific types of leisure-time physical activity simultaneously at age 15 predict participation in global leisure-time physical activity at age 23 ? 
- To what extent does participation in specific types of leisure-time physical activity at age 15 predict global leisure-time physical activity at age 23 ?

\section{Materials and Methods}

The problem field of our research is determined by the lack of information about youth leisure strategies. The research is carried out within the framework of a qualitative methodology, so it is important not to represent the phenomenon under study, but to understand its content specifics, based on the individual experience of informants. The selection is target-based. For the study in the questionnaire we have developed units that meet the following objectives: to characterize the features of organization of youth leisure in the city; to identify preferences of young people in leisure activities; to analyze the satisfaction of young people with forms of entertainment in the city; to ascertain the awareness of respondents about the work of the institutions in socio-cultural sphere on the organization of leisure of youth in the city; to identify barriers to leisure activities of young people in accordance with their needs; to analyze how the employment status of respondents affects the availability of free time; identify how young people actually spend their leisure time and how they would like to spend it; consider alternative forms of leisure activities.

Questions used in the questionnaire.

How do you estimate the amount of your free time? (If it is not enough, why?)

How do you assess your city based on the availability of places and opportunities for leisure activities?

Do you have a hobby or interests?

How do you like to spend your free time?

How do you usually plan your leisure time?

How do you assess the availability of opportunities to pursue your hobby in our city?

Can you name any cultural and entertainment events that have taken place in our city over the past six months?

How do you see your ideal leisure time?

What forms of leisure, which are not available in our city, you would be interested in? If there were these opportunities in the city, would you participate in these forms of leisure?

What do you think prevents you from spending leisure time according To your needs?

Have you tried to organize any forms of leisure activities yourself, ask for support from the youth Department or public organizations, and why? If you applied, what was the result?

\section{Results}

First, we were interested in the question of how young people like to spend their free time. The answers to this question were very diverse. But it is obvious that these are the most common home forms of spending free time (77\%) and they do not require any additional costs (computer, reading, spending time with friends or just relaxing in silence) in the absence of any social contacts outside the house and any attempts to somehow diversify your leisure time inside the house are the simplest type of leisure activity. Some informants noted that they considered sleep as a leisure time, because they gained strength at this time, and thus rested (13\%).

It is necessary to recognize that for a large part of the city's young people, what is attractive in leisure is not how they spend it, but what meaning they put into it. The goal is emotional relief, distraction from the main activity (56\%). However, among the informants there were also those who liked to diversify their regular leisure with active forms of spending time (44\%).

In terms of leisure activities, the majority of young people are almost unanimous (96\%). They plan it spontaneously. Nevertheless, there were also those who were more organized about leisure (4\%). These informants were most interested in spending their free time with an emphasis 
not only on rest and on relaxation, but also getting new skills and information. That is, even the time for rest they planned so that it was spent as productively as possible.

It is worth noting that informants who plan their leisure time have more employment during the day (64\%) than those who do not plan it.

One of the main objectives of the study was to find out how the city's young people evaluate their city based on the availability of places and opportunities for leisure activities. Only $13 \%$ of informants have a positive opinion about the possibilities of spending free time. We can say that such positive views are associated with the emergence of new social, cultural and sports institutions and clubs in the city.

All other respondents (87\%) did not share this opinion. It turned out that their discontent is due to several reasons: the lack of places to spend free time; monotony of choice. Active leisure begins only if the range of leisure preferences is expanded due to non-domestic types of cultural, entertainment, recreational, social or other activities. This is what makes people's social life the most complete and affects their level of satisfaction with this area of life, which is not noticed by the residents of the city. An unsatisfactory assessment by informants of leisure in the city was also manifested in the ability to engage in their hobby, a favorite affairs, which, as it turned out, almost everyone has $(91 \%)$. Most often, this is due to the impossibility of further development and growth in various areas, even if there is a decent potential. The lack of resources or their poor quality was also a problem. Informants engaged in various sports $(23 \%)$ noted the lack of available fields, sites, and a small number of different competitions to demonstrate their abilities. In this regard, in part, many talented people do not receive proper attention, but could perform at a high level. One of the important problems is the lack of initiative and lack of awareness of young people in the field of leisure activities held in the city. This is due both to the disinterest of the informants themselves, due to the discrepancy between their interests, needs and the age composition of participants with the ongoing events, and to the passive agitation of the organizers of the Department of culture, as evidenced by the weak awareness of young people about current cultural and entertainment events.

The study found that more than half of young people (77\%) not only consider such institutions as hookah Bars to be useless organizations for leisure, but also see this as a problem, since they note an unfavorable contingent that carries potential and real cases of deviant behavior. However, it would be unfair to say that all the respondents shared this position. Cultural events were named. An interesting fact is that some informants (13\%) separate time for their Hobbies and interests from leisure time. This was especially evident when answering the question about the amount of time that young people spend on leisure. In General, young people rated the availability of free time that they could spend for fun, positively. The majority $(73 \%)$ have enough of it, as they say. Representatives of the student body (65\%) note that a large amount of time is spent on the road to study.

\section{Discussion}

One of the objectives of the study was to study the reasons why young people do not have the opportunity to spend their leisure time in accordance with their needs. Opinions were divided about equally. Some believed that external reasons were the reason for it - the lack of places, the lack of interest of the organizers, the city's population is too small, and therefore certain forms of leisure are not attractive and unprofitable for entrepreneurs. Some noted high prices for services provided and non-compliance with cultural norms. Some noted strong employment at work, lack of energy after it, but there were also those who found the reasons in themselves. Those respondents who spend their leisure time on the Internet, playing computer games, watching videos, or reading web articles, noted that they could easily free up a whole day for free time spending if necessary. They are not burdened with work, study, or household chores-reasons that are a problem for other informants. During the interview, we gave informants the opportunity to 
describe how they imagine their ideal leisure time. Many have noticed that it is very different from the real one. These are leisure activities that are not represented in the city, but would be in demand.

The actual situation of leisure activities coincides with how the informants spoke about how they like to spend their free time. Mostly, these are meetings with friends, going to the cinema, learning languages, computer games, watching movies at home. Less often - reading, sharing creativity with all family members, listening to music.

As alternative forms of leisure that young people would like to see in the urban environment, as well as take part in them, informants noted the following: cinemas, theaters; restaurants; amusement parks, attractions; master classes, courses, exhibitions; interest clubs (language, discussion, computer); Bicycle rental, roller skates, Quad bikes, go-karts; paragliding school; industrial tourism. None of the respondents asked for help to representatives of the youth Department. Most often, young people explained this position by lack of time, not knowing whom to address to on this issue. As well as the reluctance of the organizers to change the situation.

\section{Conclusion}

There is no doubt that significant changes have taken place in the sphere of youth leisure. New forms of leisure activities are emerging, and the nature and content of traditional forms of leisure are changing. Today it is becoming more and more obvious that modern types of youth leisure activities have features that significantly distinguish them from traditional types. Applied research in the field of leisure is designed to: provide a diagnosis of the state of the socio-cultural sphere; find out the nature of the dependence of recreational and leisure activities on certain factors and conditions; determine the conditions and nature of the management of leisure activities. In the twenty-first century, researchers inextricably link the formation of youth's innovative potential, principles, priorities, and life positions with the impact of the information environment and advanced communication technologies on them. Since in modern society, information has acquired the role of a catalyst for various processes that form the personality and worldview of young people in the process of socialization, it is certainly an effective and efficient tool for influencing society. An important task of the study is to study the reasons why young people do not have the opportunity to build a strategy for their leisure time in accordance with their needs.

Regarding the interaction of young people with leisure and cultural organizations, it turned out that none of the respondents addressed relevant questions to representatives of the Department of youth. Most often, this was justified by the lack of time, not knowing whom to address on this issue. As well as the unwillingness of the organizers to change situation, that is, ignoring the positions of young people, according to informants. As a result, young people show little interest in leisure activities organized by the authorities, since they are formal in nature and do not correspond to their leisure preferences, are unattractive for them and unprofitable for entrepreneurs.

Regarding the interaction of young people with leisure and cultural organizations, it turned out that none of the respondents addressed relevant questions to representatives of the Department of youth. Most often, this was justified by the lack of time, not knowing whom to address on this issue. As well as the unwillingness of the organizers to change the situation, that is, ignoring the positions of young people, according to informants. As a result, young people show little interest in leisure activities organized by the authorities, since they are formal and do not correspond to their leisure preferences. New forms of leisure activities are emerging, and the nature and content of traditional forms of leisure are changing. Today it is becoming more and 
more obvious that modern types of youth leisure activities have features that significantly distinguish them from traditional types. However, in small towns, opportunities for modern leisure activities are very limited. Of course, large cities have more developed infrastructure and more opportunities not only in the field of leisure and recreation, but also in various fields, such as sports, art, and decorative and applied art.

\section{References}

Akimova, L.A. (2003). Sociology of leisure. Teaching Aid. Moscow: Moscow state University of culture and arts.

Alisov, E.A., Cherdymova, E.I., Trubina, G.F., Yakushev, A.N., Zhdanov, S.P., Popova, O.V., \& Kobzar-Frolova, M.N. (2018). Study of Dominant Type of Student Ecological Focus. Ekoloji, 27(106), 357-362.

Aryamova, T.V., \& Nedoseka, E.V. (2012). Dynamics of leisure preferences of young people at the turn of the century. URL: httPs://cvberleninka.ru/article/n/dinamika-dosugowhpredpochteni-v-molodezhi-na-rubezhe-vekov (accessed 17.01.2020).

Baranov, V.V., Cherdymova, E.I., Novikov, S.B., Lukina, E.V., Kazurov, O.A., Korzhanova, A.A., \& Gurbanov, R.A. (2019). Student attitude to ethical consumption as new ecological practice. Humanities \& Social Sciences Reviews, 7(4), 1173-1179.

Bestuzhev-Lada, I.V. (1984). Youth and maturity: Reflections on some social problems of youth. Moscow: Politizdat.

Bolgov, V.I. (2003). Sociological analysis of new forms of socio-cultural life. Socis, 2, 34-37.

Cherdymova, E.I., Afanasjeva, S.A., Parkhomenko, A.G., Ponyavina, M.B., Yulova, E.S., Nesmeianova, I.A., \& Skutelnik, O.A. (2018a). Student ecological consciousness as determining component of ecological-oriented activity. EurAsian Journal of BioSciences Eurasia J Biosci, 12, 167-174.

Cherdymova, E.I., Vorobyeva, K.I., Romashkova, O.V., Mashkin, N.A., Grigoriev, S.M., Romanchenko, L.N., Karpenko, M.A., \& Bayanova, A.R. (2018b). Photo Exhibition Influence on Student Environmental Consciousness Formation. Ekoloji, 27(106), 12711278.

Denisova, R.V., \& Lenkova, R.V. (2015). Sociology of youth: textbook for academic baccalaureate. Moscow: Publishing House of Youwrite Series: The Bachelor. Academic course.

Drobinskaya, E.I., \& Sokolov, E.V. (1983). Free time and personal development. Leningrad: Leningr. Org of society "Znaniye" of the Russian Soviet Federal Socialist Republic.

Eroshenko, I.I. (1986). Work of club institutions with children and teenagers. Moscow: Prosvescheniye.

Ionin, L.G. (2000). Sociology of culture: the path to the new Millennium. Moscow: Logos.

Kiseleva, T.G., \& Krasilnikov, Yu.D. (2005). Fundamentals of social and cultural activities. Moscow: Publishing house of Moscow state University of culture.

Lukov, V.A. (2002). Features of youth subcultures in Russia. Sociological research, 10, 79-88.

Maskevich, A.B. (1989). Man in his spare time: Opinion of a sociologist. Minsk: Nauka i tekhnika.

Myalkin, A.V. (1983). Ability and needs of the personality: dialectics of formation. Moscow: Mysl.

Nedoseka, E.V. (2013). On the problem of youth leisure organization in the Murmansk region. URL: https://cvberleninka.ru/article/n/k-probleme-organizatsii-dosuga - moldezhi-vmurmanskov-oblasti (accessed 08.01.2020).

Nikolov, L. (1984). Structures of human activity. Moscow: Progress.

Orlov, G.P. (1983). Free time and personality. Sverdlovsk: Publishing house of the Ural University.

Ponukalkina, O.V. (2008). Virtual leisure Civilization of the Russian province. URL: https://cvberleninka.rU/article/n/virtualnava-tsivilizatsiva-dosuga-rossivskovprovintsii (accessed 01.01.2020). 
Putilina, E.S., Cherdymova, E.I., Kurbanov, R.A., Belyalova, A.M., Shatskaya, I.I., Kobzeva, E.I., Zhuravleva, M.V., \& Meleshko, G.S. (2019). Ecological relationships in real and virtual environments: contact points. EurAsian Journal of BioSciences Eurasia J Biosci, $13,1475-1480$.

Shmelev, A.A. (1998). Youth cultural and social movements in Russia. Socis, 8, 49-54.

Streltsov, Yu.A. (2003). Cultural studies of leisure. Moscow: Moscow state University of culture and arts.

Surtaev, V.Ya. (1999). Youth and culture. St.Petersburg: St. Petersburg publishing house state University of culture and arts.

Tsybin, Yu.E., \& Golubev, L.V. (1988). Youth. Leisure. Music. Moscow: Science and technology. Vishnyak, V.I., \& Tarasenko, A.I. (1988). Culture of youth leisure. Kiev: Higher school.

Zharkov, A.D. (2007). Theory and technology of cultural and leisure activities: Textbook for students of higher education institutions of culture and arts. Moscow: Publishing House of Moscow state University of culture and arts.

Zhurik, T.S., \& Sherstyukova, E.A. (2013). The role of leisure organization in the development of a student's personality on the example of the Belgorod region. Scientific result. Pedagogy and psychology of education, 4(3), 11-18. 